\title{
PERENCANAAN STRATEGIS DAN SISTEM ARSITEKTUR INFORMASI (STUDI KASUS DI PDAM KABUPATEN MAJALENGKA)
}

\author{
Harun Sujadi, S.T. \\ Fakultas Teknik, Universitas Majalengka \\ harunsujadi@gmail.com
}

\begin{abstract}
Bagi perusahaan memiliki strategi bisnis saja tidak cukup untuk menghadapi persaingan dewasa ini yang semak in ketat. Strategi bisnis yang biasa dituangkan dalam dokumen atau cetak biru Business Plan harus pula dilengkapi dengan strategi teknologi informasi atau I/T Strategy. Persaingan yang semakin meningkat dan ketat dalam bidang penyediaan air bersih sudah barang tentu memerlukan suatu strategi yang jitu guna memenangkan persaingan tersebut. Dalam upaya mencapai tujuan Perusahaan Daerah Air Minum (PDAM) di Kabupaten Majalengka yang dirumuskan dalam visi dan misi, memerlukan suatu strategi bisnis yang didukung dengan strategi SI/TI. Untuk memenangkan persaingan dalam kompetisi tersebut, PDAM Kabupaten Majalengka merancang suatu rencana strategis SI/TI yang selaras dengan strategis bisnis. Untuk membuat rencana strategis SI/TI yang baik, diperlukan suatu kerangka kerja yang dapat memberikan peran strategis SI/TI dalam organisasi, dapat meningkatkan nilai (value) bisnis serta dapat menciptakan keunggulan kompetitif (competitive advantage) PDAM Kabupaten Majalengka.

Hasil yang dicapai dari penelitian adalah membuat suatu kerangka kerja perencanaan strategi SI/TI yang terintegrasi sehingga memudahkan manajemen mengelola sumberdaya yang tersedia untuk menghasilkan informasi yang dibutuhkan, akurat, tepat waktu, dan dapat digunakan secara bersama oleh pihak-pihak yang berkepentingan dan merancang sebuah arsitektur PDAM di Kabupaten Majalengka.
\end{abstract}

Kata Kunci : Perencanaan, Strategi, Arsistektur, Sistem, Teknologi Informasi.

\section{PENDAHULUAN}

Perkembangan pemakaian teknologi informasi (TI) saat ini semakin meningkat di berbagai industri. Hal ini terjadi dengan suatu kesadaran bahwa pemamfaatan informasi yang baik dan benar tidak hanya akan memberikan efisiensi dan meningkatkan produktifitas, tetapi juga akan meningkatkan layanan dan keunggulan bersaing organisasi.

Kesadaran pemanfaatan teknologi informasi tersebut dilanjutkan dengan proses implementasi teknologi informasi, baik dari sisi perangkat lunak (software) maupun perangkat keras (hardware) dan infrastruktur. Tentu saja dengan harapan agar teknologi informasi yang dibangun mampu memberikan mamfaat sesuai dengan yang diharapkan.

Namun sering ditemukan bahwa penerapan TI kurang berpengaruh terhadap peningkatan kinerja dan kesuksesan bisnis organisasi maupun peningkatan daya saing organisasi. Hal tersebut terjadi akibat penerapan TI yang hanya berfokus pada teknologinya saja. Oleh karena itu, cara efektif untuk mendapatkan manfaat strategis dari penerapan TI adalah dengan berkonsentrasi pada kaji ulang bisnis (rethinking business) melalui analis is masalah bisnis saat ini dan perubahan lingkungannya serta mempertimbangkan TI sebagai bagian solusi (Earl, 1992).
Permasalahan lain dalam penerapan TI adalah investasi TI masih belum berhasil memberikan manfaat yang diharapkan kepada organisasi (Ward and Peppard, 2003). Pimpinan perusahaan sering dihadapkan pada kenyataan bahwa belanja modal (capital expenditure) untuk TI tidak membuahkan hasil hingga nilai tertentu sesuai dengan besarnya investasi yang telah dilakukan. Perusahaan menggunakan TI untuk pengelolaan akuntansi dan keuangan, operasional pemasaran, layanan pelanggan, koordinasi antar kantor cabang, perencanaan produksi, pengendalian persediaan, mengurangi lead time, melancarkan distribusi dan lain sebagainya. Namun tidak jelas apakah penggunaan TI semacam ini sudah secara nyata menghasilkan output yang lebih banyak (Robert Solow dan McCarty, 2001).

Salah satu penelitian tentang Langkah-langkah Perencanaan Strategis Sistem Informasi oleh Ari Wedhasmara, dari hasil penelitian tersebut dapat diambil suatu kesimpulan bahwa Untuk bisa menerapkan pengelolaan teknologi informasi yang baik, diperlukan perencanaan strategis pengembangan sistem informasi sehingga pola investasi dan pengembangan sistem yang akan dilakukan berjalan sesuai dengan tahapan-tahapan yang telah ditentukan sebelumnya, serta agar penerapan TI Optimal dibutuhkan suatu strategi TI 
yang selaras dengan strategi bisnis organisasi. Begitu pula dengan PDAM Kabupaten Majalengka, merupakan salah satu perusahaan milik daerah yang bergerak dibidang penyediaan kebutuhan air bersih bagi kepentingan publik yang saat ini terus melakukan pembenahan dan peningkatan pelayanan diberbagai aspek dengan tujuan untuk meningkatkan daya saing. Sehingga melihat kondisi tersebut sudah sewajarnnya PDAM Kabupaten Majalengka memodelkan Perancangan Strategis Sistem Informasi guna mendukung tujuan dari perusahaan tersebut.

\section{IDENTIFIKASI MASALAH}

Untuk menentukan strategi TI yang dapat mendukung pencapaian visi dan misi organisasi, maka perlu pemahaman tentang strategi bisnis organisasi. Pemahaman tersebut mencakup penjelasan terhadap hal-hal berikut : mengapa suatu bisnis dijalankan, kemana tujuan, dan arah bisnis, kapan tujuan tersebut dicapai, bagaimana cara mencapai tujuan dan adakah perubahan yang harus dilakukan. Jadi dalam membangun suatu strategi SI/TI, yang menjadi isu sentral adalah penye larasan (alignment) strategi SI/TI dengan strategi bisnis organisasi.

\section{TUJUAN}

Tujuan dari Perencanaan Strategis Sistem Informasi ini, yaitu :

1. Mengidentifikasi kebutuhan informasi yang dapat menunjang operasional perusahaan.

2. Menghasilkan usulan perencanaan strategi sistem dan teknologi informasi pada PDAM Kabupaten majalengka

3. Merancang sebuah arsitektur jaringan sistem informasi pada PDAM Kabupaten Majalengka

\section{METODOLOGI PENGEMBANGAN}

Membahas mengenai hasil analisis dari informasi tentang organisasi PDAM Kabupaten Majalengka, proses bisnis yang ada, penanganan permasalahan dan pemecahannya terkait dengan penggunaan teknologi informasi. dan Metode yang dipakai dalam perencanaan strategis sistem informasi yang akan digunakan mengacu pada konsep Ward and Peppard.

1. Metodologi Perencanaan Strategis Sistem Informasi menurut John Ward dan Peppard .

Konsep pemikiran Perencanaan Strategis SI/TI dari John Ward berangkat dari adanya kondisi investasi SI dan TI di masa lalu yang kurang dapat memberikan manfaat bagi tujuan bisnis organisasi, menangkap peluang bisnis, dan adanya fenomena semakin meningkatnya keunggulan kompetitif organisasi karena mampu memanfaatkan potensi SI dan TI. Keadaan tersebut dapat terjadi karena rencana strategis SI dan TI yang kurang fokus pada bisnis, dilakukan oleh bagian yang kurang mengerti peluang bisnis, dan hanya membuat strategi karena kebutuhan teknologi semata. Oleh karena itu John Ward membuat kerangka Perencanaan Strategis SI/TI yang didasarkan pada kebutuhan bisnis. Tahapan-tahapan Perencanaan Strategis SI/TI tersebut dibagi dalam 2 tahapan yaitu tahapan masukan dan tahapan keluaran.

\section{ANALISIS SWOT}

Analisis SWOT (Strengths, Weaknesses, Opportunities, Threats ) digunakan untuk menilai kekuatan-kekuatan dan kelemahan-kelemahan dari sumber daya yang dimiliki oleh organisasi/perusahaan dan kesempatan-kesempatan eksternal dan tantangan-tantangan yang dihadapi.

1. Mengidentifikasi kekuatan-kekuatan organisasi/perusahaan dan kemampuan sumber dayanya. Suatu kekuatan adalah sesuatu yang baik yang dilakukan oleh organisasi/perusahaan atau suatu karakteristik organisasi/perusahaan yang meningkatkan daya saing. Suatu kekuatan dapat berupa beberapa wujud sebagai berikut :
a. Suatu keahlian atau kepandaian.
b. Aktiva fisik yang bernilai.
c. Aktiva manusia yang bernilai.
d. Aktiva organisasi yang bernilai.
e. Aktiva tidak berwujud yang bernilai.
f. Kemampuan kompetensi.
g.Suatu prestasi atribut yang meletakkan organisasi/perusahaan diposisi menguntungkan di pasar supaya menjadi terkemuka dipangsa pasar.
h. Kerjasama atau saling menguntungkan.

2. Mengindentifikasikan kelemahan perusahaan dan kecacatan sumber dayanya. Suatu kelemahan adalah sesuatu yang perusahaan tidak memilikinya atau yang dilakukan dengan jelek atau kondisi yang meletakkan perusahaan ke posisi tidak menguntungkan. Kelemahan-kelemahan internal didalam organisasi/perusahaan dapat berupa sebagai berikut :

a. Kemampuan sumber daya yang terbatas berhubungan dengan kompetisi.

b. Tidak mempuyai aktiva fisik, manusia, organisasi atau aktiva tidak.

b. berwujud yang penting untuk berkompetis i.

c. Kehilangan atau melemahnya kemampuan kompetisi di area-area kunci.

3. Mengidentifikasikan kesempatan pasar. Strategi yang baik adalah dapat mengarahkan kekuatan dan kelemahan sumber daya organisasi/perusahaan untuk meraih kesempatan pasar yang ada. Kesempatan pasar yang paling relevan adalah dapat 
meningkatkan pertumbuhan keuntungan, meningkatkan sesuatu yang dapat membuat organisasi/perusahaan mendapat keuntungan kompetitif dan yang sesuai dengan kemampuan sumber daya keuangan dan organisasi yang sudah dimiliki oleh perusahaan atau nantinya dapat dimiliki.

4. Mengidentifikasikan ancaman-ancaman yang dihadapi oleh perusahaan dimasa akan datang. Beberapa faktor lingkungan luar organisasi/perusahaan yang dapat menyebabkan ancaman terhadap keuntungan dan posisi pasar perusahaan.

Ancaman-ancaman dapat berupa munculnya teknologi baru yang lebih murah, produk yang lebih baik dan lebih baru yang dikenalkan oleh masingmasing pesaing dan yang lainnya. Tugas dari manajemen adalah mengidentifikasikan ancamanancaman ini dan kemudian mengevaluasinya untuk menentukan strategi apa yang harus dilakukan untuk menetralkan atau mengurangi pengaruh dari ancaman tersebut.

Dengan demikian menganalis is kekuatankekuatan perusahaan dan kemampuan sumber daya yang dimiliki perusahaan dan kesempatan eskternal dan tantangan yang dihadapi meliputi hal-hal sebagai berikut :

1. Mengidentifikasikan kekuatan-kekuatan perusahaan dan kemampuan sumber dayanya untuk dapat membangun kemampuankemampuan kompetisi.

2. Mengidentifikasikan kelemahan-kelemahan perusahaan dan kelemahaan sumber dayanya.

3. Menangkap kesempatan-kesempatan pasar yan paling sesuai dengan kemampuan sumber daya perusahaan.

4. Mempertahankan ancaman-ancaman dari luar terhadap bisnis perusahaan dengan membangun suatu basis sumber daya yang dapat digunakan mempertahankan dari ancaman tersebut.

Analisis SWOT dapat digunakan untuk menganalisis kekuatan-kekuatan dan kelemahankelemahan sumber daya organisasi/perusahaan, peluang dan ancaman luar perusahaan. Analisis SWOT tidak hanya mengidentifikasikan keempat hal tersebut saja tetapi harus dapat digunakan untuk menarik kesimpulan sebagai berikut ini :

1. Bagaimana cara terbaik untuk menggunakansumber daya perusahaan dengan mempertimbangankan situasi internal dan eksternal perusahaan, yaitu untuk membangun kompetitisi berdasarkan kekuatan internal dan peluang pasar yang tersedia, untuk mengatasi kelemahan internal yang dimiliki dan untuk mempertahankannya dari ancaman luar.

2. Bagaimana membangun basis sumber daya perusahaan dimasa depan.

\section{PERANCANGAN STRATEGI B ISNIS}

Proses perencanaan strategis memberikan urutan langkah-langkah yang bertujuan untuk mencapai puncak dalam pengembangan dan pelaksanaan yang meliputi perencanaan strategi bisnis. Langkahlangkah dalam menentukan rencana strategi bisnis terdiri dari :

1. Assesment : Aktifitas pengembangan yang transparan dan cermat, mengerti situasi bisnis dari pandangan internal dan eksternal.

2. Strategy : Mengidentifikasi apa yang diinginkan dimasa yang akan datang dari bisnis (posisi di masa yang akan datang), tujuan spesifik yang akan dicapai dan langkah strategis yang diperlukan untuk merealisasikan tujuan dan keadaan di masa yang akan datang.

3. Execution: Aksi dari perencanaan yang diusulkan kedalam tindakan. Strategi akan membuat operasional melalui program implementasi dengan membaginya kedalam multiple projects.

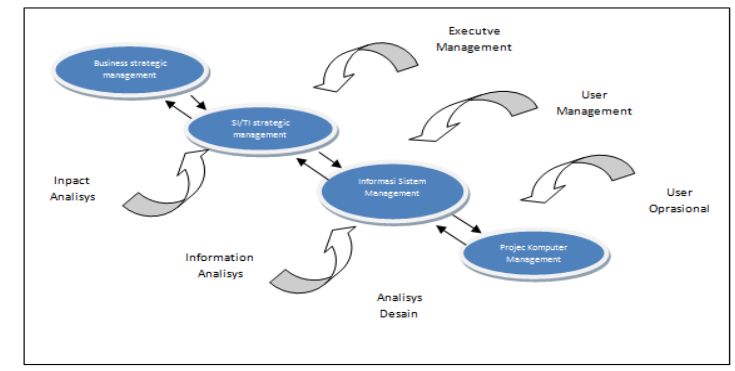

GambarKeterkaitan antara perencanaan proses bisnis dengan perencanaan sistem informasi

(Sumber : John Ward, Joe Peppard pp,39)

Tingkatan pertama dan yang tertinggi adalah business planning level tempat dimana corporate maupun individual strategic business unit yang bertanggung jawab terhadap semua elemen internal dan eksternal strategic framework. Pada tingkatan kedua yaitu business IS/IT (demand planning) menerima data dari business planning level mengenai strategi bisnis yang menjadi input utama dalam proses perencanaan strategis IS/IT. Dalam lingkungan perencanaan IS/IT yang matang, berbagai ide mengenai aplikasi informasi dan teknologi akan keluar sebagai umpan balik bagi perumusan strategi bisnis. Di level ketiga adalah tactical planning level atau IT (supply) planning yang bertanggung jawab terhadap penerjemahan IS/IT (demand planning) menjadi perencanaan penyediaan infrastruktur dan jasa teknologi informasi. Perencanaan di tingkatan ini akan menggunakan informasi kebutuhan pengguna (user requirements) serta beberapa analis mengenai keahlian, sumber daya dan kapasitas serta data lain agar penyediaan infrastruktur dan jasa teknologi 
informasi tersebut sesuai dengan apa yang diharapkan. Pada tingkatan terakhir ialah development and implementation activities sebagai penerapan dari IT (supply).

planning. Tingkatan ini perlu memperhatikan tingkat kepuasan pengguna dan secara terus menerus meningkatkan kualitas teknologi informasi hasil evaluasi efektifitas dan analis is dampak serta ide-ide inovatif yang potensial.

Karena keterkaitan yang begitu erat antara perencanaan strategi bisnis dengan perencanaan strategis untuk sistem informasi seperti yang digambarkan pada gambar 2.7 pada halaman 30, maka dengan menggabungkan keduanya, langkahlangkah diatas dapat diaplikasikan untuk perencanaan strategi bisnis dan perencanaan sistem informasi.

\section{ARSITEKTUR INFORMASI}

Arsitektur informasi atau arsitektur teknologi informasi atau arsitektur sistem informasi atau infrastruktur teknologi informasi adalah suatu pemetaan atau rencana kebutuhan-kebutuhan informasi di dalam suatu organisasi (Turban, McLean, Wetherbe, 1999). Arsitektur ini berguna sebagai penuntun operasi sekarang atau menjadi cetak biru (blueprint) untuk arahan dimasa mendatang. Tujuan dari arsitektur ini adalah agar bagian teknologi informasi memenuhi kebutuhankebutuhan bisnis strategi organisasi. Oleh karena itu, arsitektur informasi memadukan kebutuhan informasi, komponen sistem informasi, dan teknologi pendukung sebagaimana diperlihatkan pada gambar

Tabel Definisi Arsitektur Informasi

\begin{tabular}{|l|l|}
\hline \multicolumn{1}{|c|}{ SUMBER } & \multicolumn{1}{|c|}{ DEFINISI } \\
\hline Loudon (1998) & $\begin{array}{l}\text { Arsitektur Informasi adalah bentuk khusus yang } \\
\text { menggunakan teknologi informasi dalam organisasi } \\
\text { untuk mencapai tujuan-tujuan atau fungsi-ungsi yang } \\
\text { telah dipilih. }\end{array}$ \\
\hline Zwass (1998) & $\begin{array}{l}\text { Arsitektur Informasi adalah desain sistem komputer } \\
\text { secara keseluruhan (termasuk sistem jaringan) untuk } \\
\text { memenuhi kebutuhan-kebutuhan organisasi yang } \\
\text { spesifik. }\end{array}$ \\
\hline
\end{tabular}

Sumber : Kadir, A, $2003: 73$

Gambar melukiskan bahwa arsitektur informasi mencakup area fungsional (keuangan, akuntansi, dan sebagainya) dan juga sistem-sistem yang mendukungnya (seperti TPS dan MIS).

Sebagai contoh arsitektur informasi dapat dilihat pada Gambar sebagai berikut :

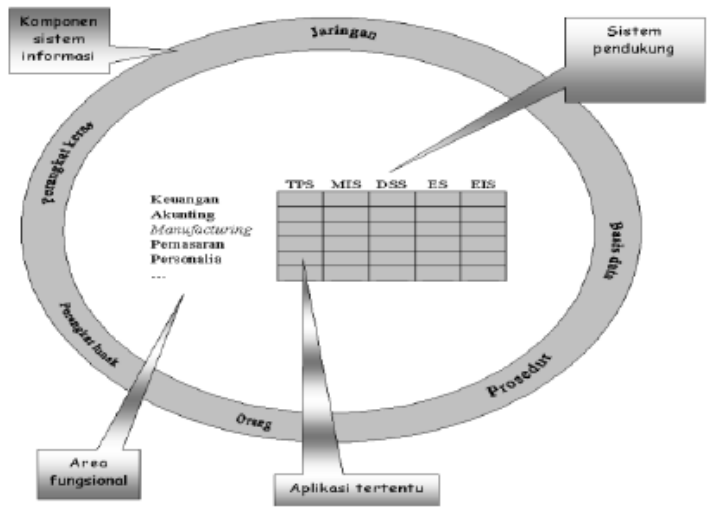

Gambar Skema Arsitektur Informasi (Sumber : Turban ,McLean dan Wetherbe, 1999) 
Gambar dibawah ini merupakan salah satu contoh dari implementasi arsitektur informasi

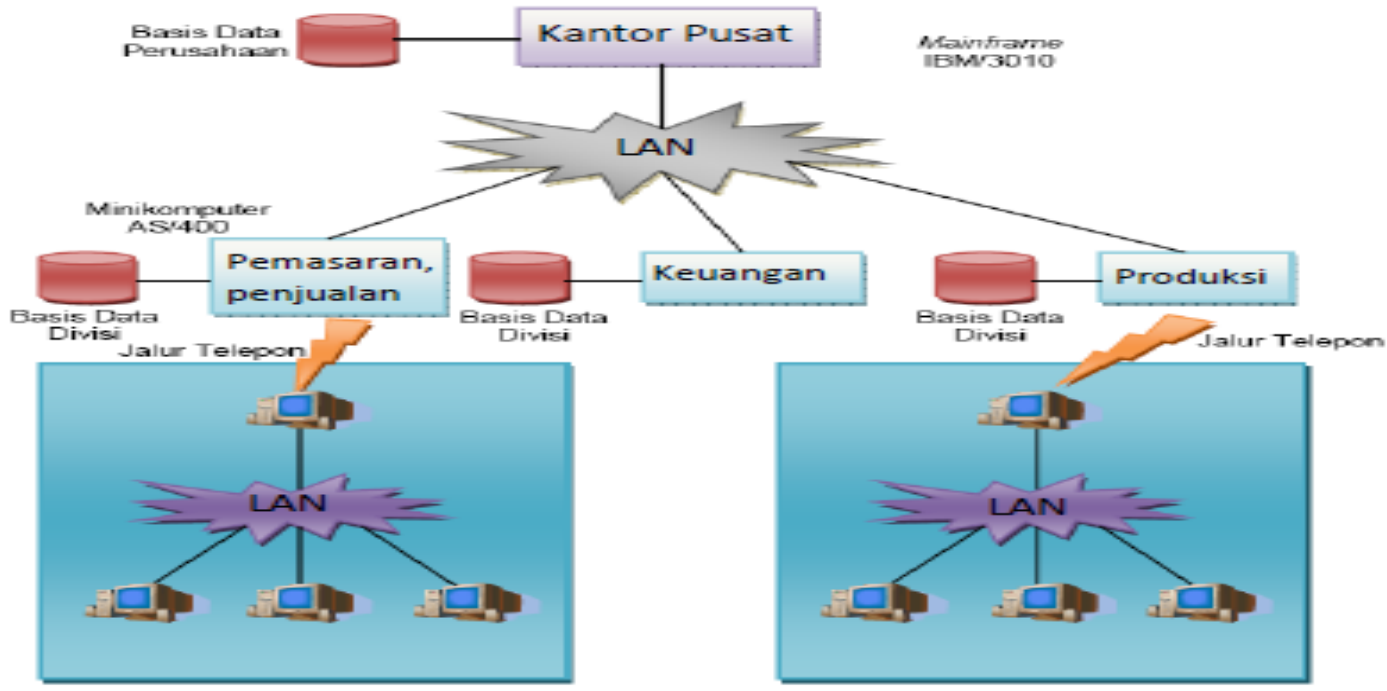

Gambar Contoh Arsitektur Informasi (Sumber : Turban „McLean dan Wetherbe, 1999)

8. Dalam tahapan perancangan, yang dilakukan adalah :

1. Pembuatan Arsitektur Informasi

Pembuatan arsitektur informasi bertujuan untuk menghubungkan fungsi bisnis dengan subyek data berdasarkan pengelompokan fungsi berupa area bisnis. Produk yang dihasilkan dalam tahap ini berupa matriks fungsi bisnis vs subyek data yang sudah dikelompokan, fungsi bisnis vs subyek data model dan area bisnis.

2. Pembuatan Matriks Fungsional

Matriks fungsional dibuat guna mengetahui keterkaitan antara area bisnis satu dengan yang lainnya melalui subyek data yang tersedia. Produk yang dihasilkan pada tahap ini berupa matriks fungsi bisnis vs subyek data keterkaitan.

3. Pembuatan Jaringan Komunikasi Infrastruktur dan Aturan

Disesuaikan dengan hasil analisis guna kepentingan implementasi saat ini dan mendatang.

4. Pembuatan ERD
Berdasarkan keterhubungan fungsional /entitas guna pengembangan basis data/aplikasi sesuai dengan tujuan organisasi.

\section{IMPLEMENTASI} STRATEGIS SI/TI

Dengan adanya kerangka kerja perencanaan strategis SI/TI yang diusulkan pada bab sebelumnya, maka pada bab ini dilakukan implementasi kerangka kerja tersebut guna membuat perencanaan strategis SI/TI di PDAM Kabupaten Majalengka. Adapun visi dari perencanaan strategis SI/TI adalah untuk memastikan kemana perusahaan akan dibawa, apa yang diinginkan oleh perusahaan sedangkan misi dari perencanaan strategis SI/TI adalah menje laskan mengapa TI dibutuhkan dan sekaligus diterapkan diperusahaan, tujuan dan fungsi TI serta mengkaji ulang untuk menidentifikasi tema dan ide. 
Dibawah ini uraian mengenai tabel analis is SWOT PDAM Kabupaten Majalengka :

\begin{tabular}{|c|c|c|}
\hline & $\begin{array}{l}\text { Strength (S) } \\
\text { a. Kebutuhan akan air bersih } \\
\text { b. Distribusi ke industri (non } \\
\text { domestik) } \\
\text { c. Kualitas air lebih baik terutama } \\
\text { musim kemarau } \\
\text { d. Adanya Kaporit dan PAC sebagai } \\
\text { penetralisir pH air. }\end{array}$ & $\begin{array}{l}\text { Weakness (W) } \\
\text { a. Biaya operasional masih tinggi. } \\
\text { b. Tingkat kehilangan air masih } \\
\text { cukup tinggi } \\
\text { c. Terbatasnya pasokan air baku }\end{array}$ \\
\hline $\begin{array}{l}\text { Opportunities (O) } \\
\text { a. Industri kimia sangat } \\
\text { membutuhkan air bersih } \\
\text { b. Keterbukaan supply untuk } \\
\text { domestik } \\
\text { c. Pesatnya pertumbuhan industri di } \\
\text { kawasan Tasikmalaya akan tetapi } \\
\text { terbatasnya supply air bersih } \\
\text { d. Banyak investoryang ingin } \\
\text { menanamkan modal/bermitra }\end{array}$ & $\begin{array}{l}\text { Strategi SO } \\
\text { a. Meningkatkan debit air sehingga } \\
\text { dapat memperluas cakupan } \\
\text { wilayah dalam memenuhi } \\
\text { kebutuhan air bersih. } \\
\text { b. Meningkatkan kualitas air bersih. } \\
\text { c. Meningkatkan supply air terutama } \\
\text { pada musin kemarau }\end{array}$ & $\begin{array}{l}\text { Strategi WO } \\
\text { a. Mengurangi tingkat biaya } \\
\text { operasional sehingga membuka } \\
\text { peluang bagi para investor asing. } \\
\text { b. Meningkatkan supply pasokan air. }\end{array}$ \\
\hline $\begin{array}{l}\text { Threats (T) } \\
\text { a. Proyek fasilitas pemerintah. } \\
\text { b. Teknologi yang tidak terlalu rumit, } \\
\text { sumberdaya maupun bahan baku } \\
\text { yang cukup banyak } \\
\text { memungkinkan } \\
\text { c. banyaknya pesaing baru } \\
\text { bermunculan. } \\
\text { d. Pencemaran lingkungan sumber } \\
\text { air baku. }\end{array}$ & $\begin{array}{l}\text { Strategi ST } \\
\text { Menetralisir sumber air baku yang } \\
\text { tercemar dengan menggunakan } \\
\text { kaporit dan PAC. }\end{array}$ & $\begin{array}{l}\text { Strategi WT } \\
\text { Melakukan pelatihan-pelatihan dan } \\
\text { pengembangan keahlian dalam } \\
\text { menggunakan teknologi. }\end{array}$ \\
\hline
\end{tabular}

\section{Analisis Lima Daya Porter (Porter's Five Force)}

Dengan menggunakan model Porters Five Forces, selanjutnya dilakukan analisis terhadap lingkungan eksternal. Analis is ini menggunakan 5 (lima) kekuatan yang mempengaruhi pos is i PDAM Kabupaten Majalengka dalam usaha jasa penyedia tenaga penjualan untuk meningkatkan kemampuan didalam persaingan dan peluang usaha lain serta meningkatkan competitif advantage. Analis is lima ancaman Porter ini di gambarkan pada gambar 8.1

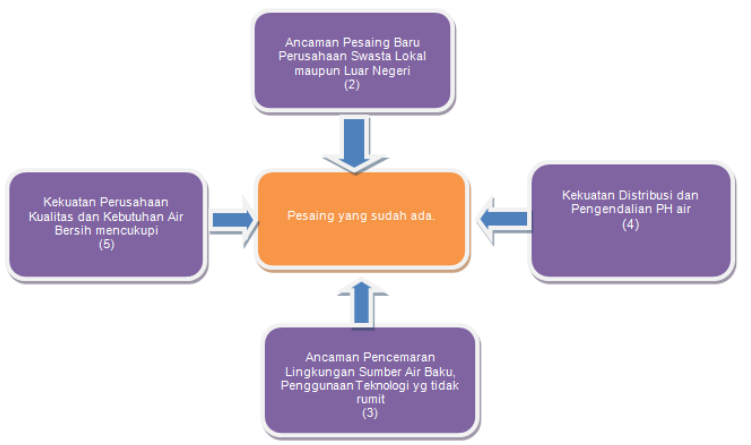

Gambar Analisis Lima Ancaman Porter PDAM Kabupaten Majalengka
Dalam analisis ini, faktor yang perlu diperhatikan antara lain ancaman pendatang baru, pesaing yang sudah ada, pencemaran lingkungan sumber air baku, penggunaan teknologi yang tidak terlalu rumit, sumber daya maupun bahan baku tersedia cukup banyak memungkinkan persaingan dari segi harga.

1. Faktor Pesaing-pesaing yang sudah ada (Current Competitor)

a. Pemberian tarif management fee yang cukup rendah.

b. Model bisnis yang berbeda antara BUMD dan Swasta.

2. Faktor Pendatang Baru

a. Pendatang baru dalam usaha ini sangat besar sekali kemungkinannya karena pada dasarnya peluang pasar masih terbuka, apalagi untuk lingkup nasional, hanya beberapa perusahaan saja yang mampu melayaninya.

b.Melihat peluang usaha yang masih luas, ancaman pesaing bukan saja datang dari perusahaan lokal namun juga sudah menarik minat perusahaan global untuk memasukinya. Hal yang betul-betul perlu diwaspadai adalah selain manajemen yang 
lebih baik mereka pun telah didukung dengan pemanfaatan teknologi informasi sebagai sarana pendukung didalam menjalankan operasionalnya.

3. Penggunaan Teknologi Yang Tidak Terlalu Sulit dan Semakin Canggih

Pesatnya perkembangan informasi dan komunikasi dewasa ini membuat perubahan didalam pola belanja yang dilakukan oleh konsumen. Konsumen menjadi semakin pintar didalam memilih produk karena semua informasi yang diperlukan relatif tersedia. Konsumen juga akan mencari tempat belanja yang nyaman dan mudah untuk mendapatkan produk yang diinginkannya. Begitu pula dengan model pasar yang semakin hari semakin berkembang, yang sangat mungkin tidak lagi diperlukannya tenaga penjualan untuk melayani konsumen karena semua informasi tentang produk dan mekanisme jual beli yang dibuat secara otomatis.
4. Faktor Pencemaran Lingkungan Sumber Air Baku

Pencemaran terhadap lingkungan sumber air baku bisa terjadi akibat alam maupun ulah manusia, dengan adanya pencemaran terhadap sumber air baku, bisa menyebabkan pruduktivitas dan distribusi a ir bersih bisa terganggu.

\section{Analis is Lingkungan SI/TI Internal}

PDAM Kabupaten Majalengka belum menerapkan sistem jaringan. Maka dari itu penelitian ini akan menerapkan teknologi informasi dalam mendukung kegiatan bisnisnya. Teknologi informasi yang digunakan meliputi teknologi jaringan yang menghubungkan seluruh divisi yang ada dalam perusahaan. Berikut adalah gambar perancangan arsitektur jaringan yang ada pada PDAM Kabupaten Majalengka.

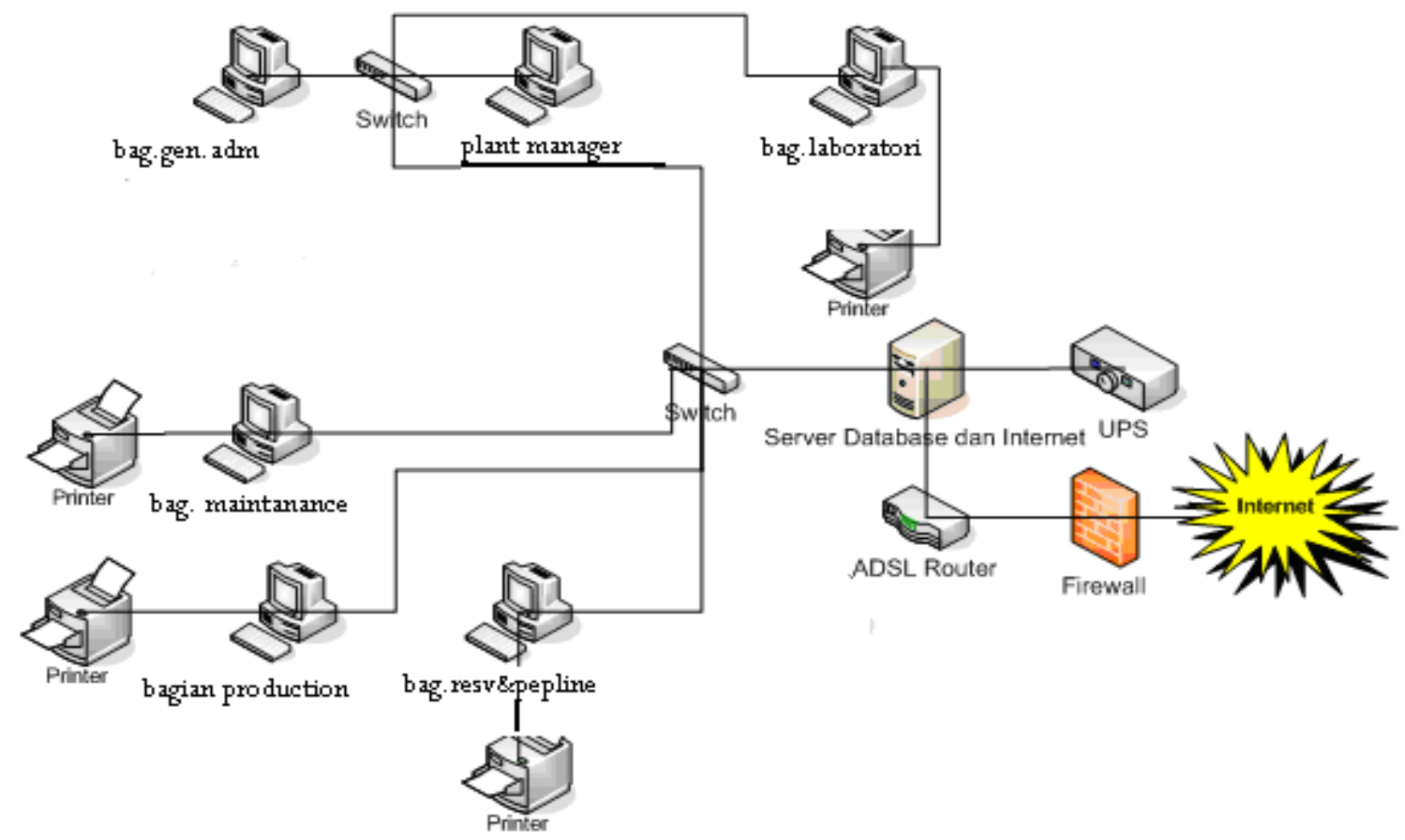

Gambar 10.1 Perancangan Jaringan Komputer Perusahaan PDAM Kabupaten Majalengka

\section{DAFTAR PUSTAKA}

1. Alter, S., Information Systems ems - The Foundation of e-Business, Prentice Hall, New Jersey, 2002.
2. Alter, Steven. Information Systems: A Management Perspective. The Benjamin/Cummings Publishing Company, Inc. 1992. 
3. Alter, Steven. The Information Systems: The Foundation of E-Business. 4th Edition, New Jersey: Pearson Education, Inc. 2002.

4. Andrews, Kenneth The Concept of Corporate Strategy, 2nd Edition. Dow Jones Irwin,1980.

5. Ari Wedhasmara, Langkah-langkah Perencanaan Strategis Sistem Informasi dengan Menggunakan Metode Ward and Peppard 2002.

6. Barry, Bryan W. Strategic Planning Workbook for Nonprofit Organizations. St. Paul, MN: Amherst H. Wilder Foundation, 1986.

7. Burlton, Roger T, Business Process Management, Profiting From Process, SAMS Publishing,Indianapolis, USA, 2001.

8. Dess, Gregory, Miller, Alex, Strategic Management, McGraw-Hill International Editions, New York, 1993.

9. Earl, M. J., "Putting IT in its place: A Polemic for the Nineties" Journal of Information Technology, vol. 7, pp. 100108M, 1992.

10. Haag, Stephen., Cummings, Maeve., Dawkins, James. Management Information Systems for the Information Age. 2nd Edition, Irwin/MacGraw-Hill. 2000.

11. Hall, James A, Sistem Informasi Akuntansi , Edisi Ketiga, Cetakan Pertama, Terjemahan : Amir Abadi Jusuf, Salemba Empat, Buku Satu, Jakarta, 2001.

12. Hall, James A. Accounting Information Systems. 3rd Edition, South Western College Publishing. 2001.

13. Harrington, H. James, Business Process Improvement, The Breakthrough Strategy For Total Quality, Productivity, and Competitiveness, McGraw-Hill Inc. New York, 1991.

14. Henderson, J.C and Venkatraman, N. Strategic Alignment: Leveraging Information Technology for Transforming Organization. IBM Systems Journal, 1993. 